\title{
"A Land of Bamboo Groves": Collective-Owned Forest Tenure Reform in Southern China and Its Environmental Impacts
}

\author{
Xiao Han ${ }^{1}$, Lloyd C. Irland ${ }^{2}$, Ying Zhang ${ }^{3}$, Jinyu Shen ${ }^{3} \&$ Yi Xie $^{3}$ \\ 1 Faculty of Forestry, University of Toronto, Canada \\ 2 The Irland Group, USA \\ 3 School of Economics and Management, Beijing Forestry University, China \\ Correspondence: Xiao Han, PhD. Candidate, Faculty of Forestry, University of Toronto, 33 Willcocks Street, \\ Toronto, ON, M5S3B3, Canada. Tel: 1-647-863-0528. E-mail: x.han@utoronto.ca
}

Received: September 5, 2013 Accepted: October 8, 2013 Online Published: February 25, 2014

doi:10.5539/jms.v4n1p125 URL: http://dx.doi.org/10.5539/jms.v4n1p125

This work was supported by the forestry public welfare scientific research project of the State Forestry Administration [Grant No. 200904003] and the National Natural Science Foundation [Grant No. 71003007].

\begin{abstract}
Environmental sustainability is a priority in China's economic and social development. This article reviews the three-decade evolvement of forest tenure reform in China's southern collectively-owned forest areas, and makes a preliminary assessment of the environmental impacts of the tenure transformation. We focus especially on an area that has been in the vanguard of reform-Sanming Prefecture in Fujian province. Transition paths that have shaped diverse forest tenure forms differ from place to place in southern China. Entirely new property rights and social relations have been created, largely on local initiative, in a brief time. De-collectivization and market oriented policies in general have supplied incentives for widespread forest planting and investment to supply new industries, with complex environmental impacts. The farmers involve express satisfaction with how the new tenure system has improved their autonomy and livelihoods. Further, systems of payments for environmental services are just beginning to emerge. However, comprehensive and integrative assessment of those effects at landscape level is in its infancy. A more adaptive strategy for monitoring effects and improving environmental performance in the land of bamboo groves is needed.
\end{abstract}

Keywords: environmental impacts, forest tenure reform, collectively-owned forest, property rights

\section{Introduction}

Apart from directly supplying timber, firewood, raw material for paper, and non-timber forest products for local livelihoods and the economy, forests have multiple environmental functions. They harbor biodiversity, present landscape beauty, anchor soil and water, store carbon, regulate climate and temper stream flow (Xu et al., 2007; Perry Oren \& Hart, 2008). Historians note the importance of past losses in China's forest area (Pomeranz, 2000; Elvin, 2006). Today, the historic shrinkage of forest area is being reversed. According to the Food and Agriculture Organization's report in 2010, there are 207 million hectares of forest land in China, ranking fifth in the world (FAO, 2010). China's forest area and growing stock volume are now growing rapidly. China now has the greatest plantation area of any country in the world, making an important contribution to reversal of the worldwide decline in forest (Note 1). The forest transition in China contributes to global carbon sequestration (Fang et al., 2001; Rudel et al., 2005), biodiversity conservation (Xu \& Melick, 2007) and to improving the local and regional environment (Blaikie \& Muldavin, 2004).

During the past few decades, one of the most prominent initiatives in China's forestry sector is the tenure reform in the southern collectively-owned forest areas. Bold steps have been taken to transform rural forestry by de-collectivizing forestland from the collectives to individual or small groups of households and other outside investors, and significantly modifying its forest management regime (Yin Yao \& Huo, 2013). The tenure reform is part of a wider, more systemic process of state transformation, rural economic development and ecological restoration. This change affects the livelihood of a large number of farmers, national ecological safety and environmental long-term interests. Recent research has primarily addressed economic effects of property right 
tenure reform (Yin \& Newman, 1997; Zhang et al., 2000; Rozelle et al., 2003; Hyde Belcher \& Xu, 2003; Wang, 2006; Yin Yao \& Huo, 2013). Limited efforts have been devoted to assessing its environmental impacts (Liu \& Landell-Mills, 2003; Lu \& Zhang, 2012; Zhang Buongiorno \& Zhu, 2012). The environmental assessment of policy decisions is one of the foremost requirements in progress towards sustainable action; that is, integrating environmentally and socially equitable considerations into strategic decision making about the entire landscape (Therivel et al., 1994; Sadler \& Verheem, 1996). Here, we present a case study of Sanming Prefecture in Fujian Province, as a microcosm for a preliminary assessment of environmental impacts of forest policy at local levels of governance. This paper is based on field work on several occasions as well as existing literature and government data sources.

The objective of this paper is to review the impacts of current pro-market land policy, and the ways forward for tenure reform in China. This paper is organized as follows: the first section introduces the history of collective-owned forest tenure reform in Southern China in general, and specifies Sanming's particular path. In the next section, we sketch the environmental impacts of the reform, highlighting several aspects, and relying on the work of others. Finally, in discussion and conclusions, we briefly outline crucial steps needed in continued improvement of the forest's environmental services.

\section{2. "Groping For Stones"-History of Collective-Owned Forest Tenure Reform in Southern China}

Property rights and tenure arrangements play a central role in national resource economics and sustainable management. The effectiveness of management depends on a group's capacity to control access to and utilization of the forest. Stability and resilience depend on the ability to adjust the management system to changes over time, maintaining a balance between the changing social and market environment and the institutions with which they controlled the forest (Menzies, 1994). Therefore, it will be useful to identify the chronology of general reform in southern areas as well as of the specific reforms in Sanming.

\subsection{Chronology of General Forest Tenure Reform in Southern Collective-Owned Forest Areas Since 1980s}

As a socialist state, China's post-1949 forestry regime has been divided into two main types: the state-owned forests of large state-run forestry bureaus and more fragmented small collective-owned forests. This fundamental institutional setting has not changed since the late 1950s when China collectivized all land in rural areas. The collective forests account for $61 \%$ of forest land area nationally, and more than $90 \%$ in the South (Anhui, Fujian, Guangzhou, Guangxi, Guizhou, Hainan, Hubei, Hunan, Jiangxi and Zhejiang). This region is home to more than 400 million people (Liu et al., 2008). Administrative villages, usually comprised of a number of natural villages (or clusters of villager families), function as the legal owners of collective forests in the majority of rural China. Collective and household management within the villages remain the primary form of operation (Xu, 2010). Over the past 30 years, the history of reform has been cyclic with initial trial followed by retrenchment and then another round of reforms and expansion. There has been a growing interest in empowering local communities, de-centralizing decision-making to local governments and getting private sector and local stakeholders' direct involvement in forest management. This has been paralleled by significant shifts in other institutional arrangements such as administration, marketing and financial investment (Table 1).

Table 1. Post-devolution tenure and management arrangements for collectively-owned forests

\begin{tabular}{|c|c|c|}
\hline Type & Tenurial arrangement & Primary decision makers \\
\hline Family plots (ziliushan) & Similar to private plots & Individual farmer households within the village \\
\hline Responsibility hills (zerenshan) & $\begin{array}{l}\text { By a special contract or with a rental } \\
\text { agreement }\end{array}$ & Individual farmer households within the village \\
\hline Partnership (Lian-Hu-Jing-Ying): & Collective contract & $\begin{array}{l}\text { A group of five to ten households formed on } \\
\text { voluntary basis }\end{array}$ \\
\hline Shareholding system & $\begin{array}{l}\text { Collective forests distributed in form of } \\
\text { share, rather than physically, to households. }\end{array}$ & $\begin{array}{l}\text { Executive Board selected by shareholding } \\
\text { households }\end{array}$ \\
\hline $\begin{array}{l}\text { Collective Management } \\
\text { (Ji-Ti-Jing-Ying) }\end{array}$ & $\begin{array}{l}\text { Owned and managed by administrative } \\
\text { village }\end{array}$ & An administrative village council \\
\hline $\begin{array}{l}\text { Villager Cluster } \\
\text { (Zi-Ran-Cun, Xiao-Zu) }\end{array}$ & $\begin{array}{l}\text { Owned and managed by a cluster of } \\
\text { households }\end{array}$ & $\begin{array}{l}\text { A cluster of families living in the same } \\
\text { neighborhood }\end{array}$ \\
\hline $\begin{array}{l}\text { Outsider Management Contract } \\
\text { (Lin-Di-Liu-Zhuan) }\end{array}$ & $\begin{array}{l}\text { Contracted out for utilization and } \\
\text { management }\end{array}$ & $\begin{array}{l}\text { Individuals and organizations residing outside } \\
\text { the villages }\end{array}$ \\
\hline
\end{tabular}

Sources: Liu (2001); Xu (2010). 
As part of its land tenure reform policy and an extension of its Household Responsibility System (HRS) in the agriculture sector, China began its experiments with new management forms for its collective forests in the early 1980s (Appendix 1 and 2). In March 1981, the State Council issued its "Resolution on Issues Concerning Forest Protection and Development," also known as "Three Fixes policy," to "fix forest landownership, fix ownership of use rights to mountains and fix responsibility for forest managements" (Liu, 2009). This initiated a new phase in the development of forest tenure by shifting toward de-collectivization and decentralization of forest use and management. This opened the door for many rural farmers and others to participate in the management, protection and utilization of collective owned forests, and has concomitantly reduced the importance of collective rights in rural affairs. By 1986, nearly $70 \%$ of the collectively-owned forestland had been transferred to rural household management (State Forestry Administration 1989). However, HRS in China's forest sector has not had the same success it had in the agriculture sector. The Three Fixes policy was followed by vast destruction of collective forests by uncontrolled cutting (Liu, 2006). Therefore, in many regions forest tenure reform was halted. The government reinstated monopolistic control of the whole timber market through price controls and detailed permit requirements. During this period, the village collective often retained control of cutting and product sales and used a variety of schemes to share benefits with the households (Liu, 2001). In the early 2000s, the Chinese government revived reform of the tenure system for collective forests, starting in a handful of provinces (Fujian, Jiangxi, Zhjiang and Liaoning). Although the reform maintained collective ownership of the forest land itself (i.e., the soil), farm households enjoy ownership rights over the standing timber and use rights of 30 to 70 years over forestland. A forestland right certificate is issued to each household to guarantee the rights to manage, develop, transfer, mortgage, and bequeath the forestland rights (Rural Land Contracting Law, 2002; Property Rights Law, 2007).

\subsection{Snapshot of Sanming's Forest Resource and Its Particular Reform Path}

There was no single reform path-instead there is significant regional variability within the collective forest regime of South China. This illustrates Deng Xiaoping's pithy saying, "Groping for stones while crossing the river." Sanming prefecture in Fujian province shares many similarities with other southern collectively-owned forest areas, but has its own unique features. This diversity makes it difficult to render general judgments on the progress and impacts of tenure reform generally.

Fujian is located in the middle range of the subtropical zone with humid climate and rich soil, favorable for tree growth. Its forest coverage rate is $63.1 \%$, the leading forested province and third forestry production region in China (Figure 1) (Sanming Forestry Administration, 2010). Traditionally, Fujian was one of earliest commercial timber production and trade regions since the Sui and Tang dynasty (581-907 AD) (Song, 1995; Songster, 2003). Its forest plantation area now ranks fourth in China (Sanming Forestry Administration, 2012).

Sanming prefecture (Note 2) is the northwestern mountainous region of Fujian province, $216 \mathrm{~km}$ from the provincial capital city-Fuzhou, about two hours' drive by highway, and is the nearest forested region to the Taiwan Strait with geographic advantage for trade and investment with Taiwanese, who share strong cultural and language links (Figure 2). Fuzhou is also a major port. 


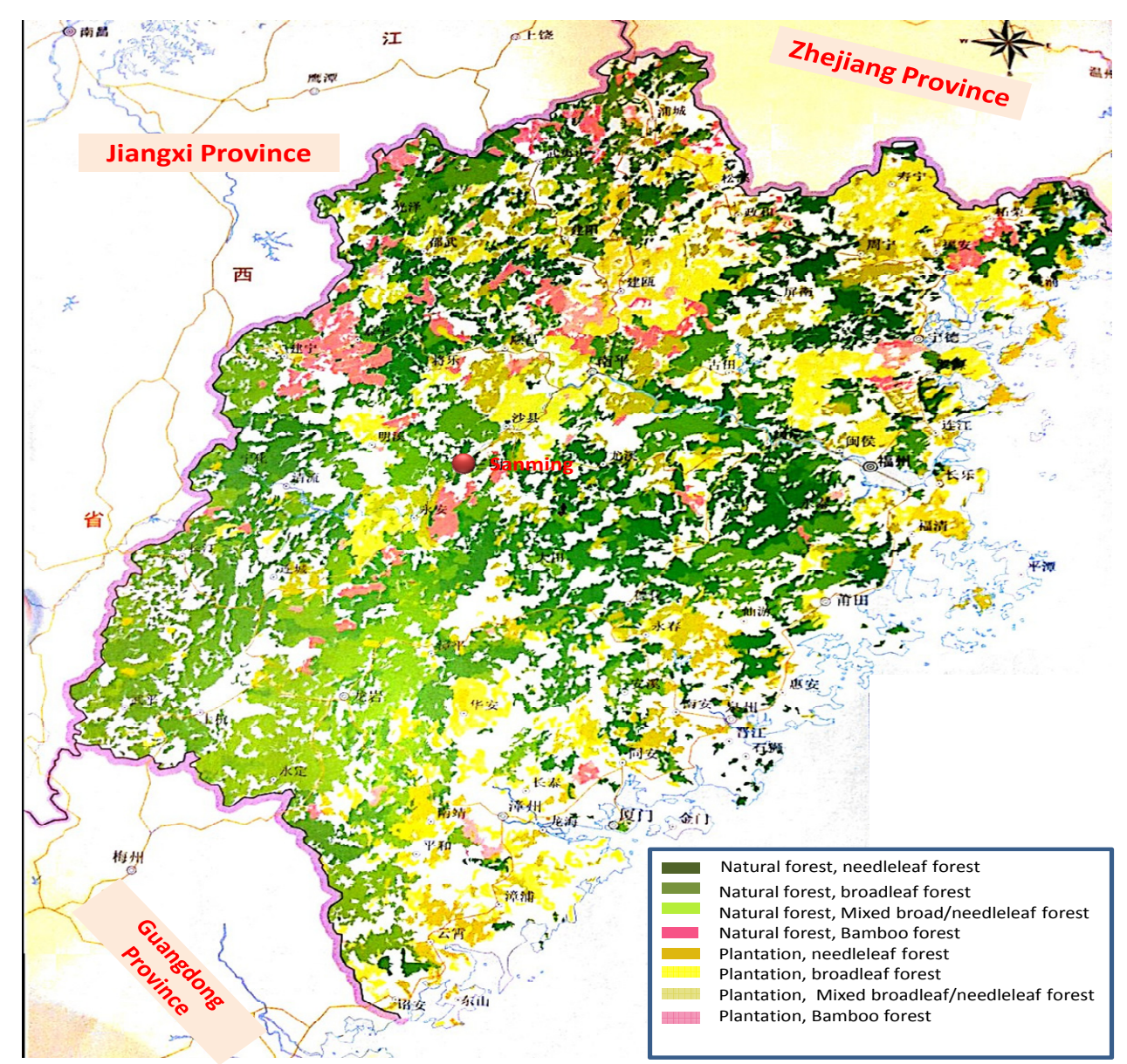

Figure 1. Distribution of forest resources in Fujian Province

Source: Atlas of Forest Resources of China (2005).
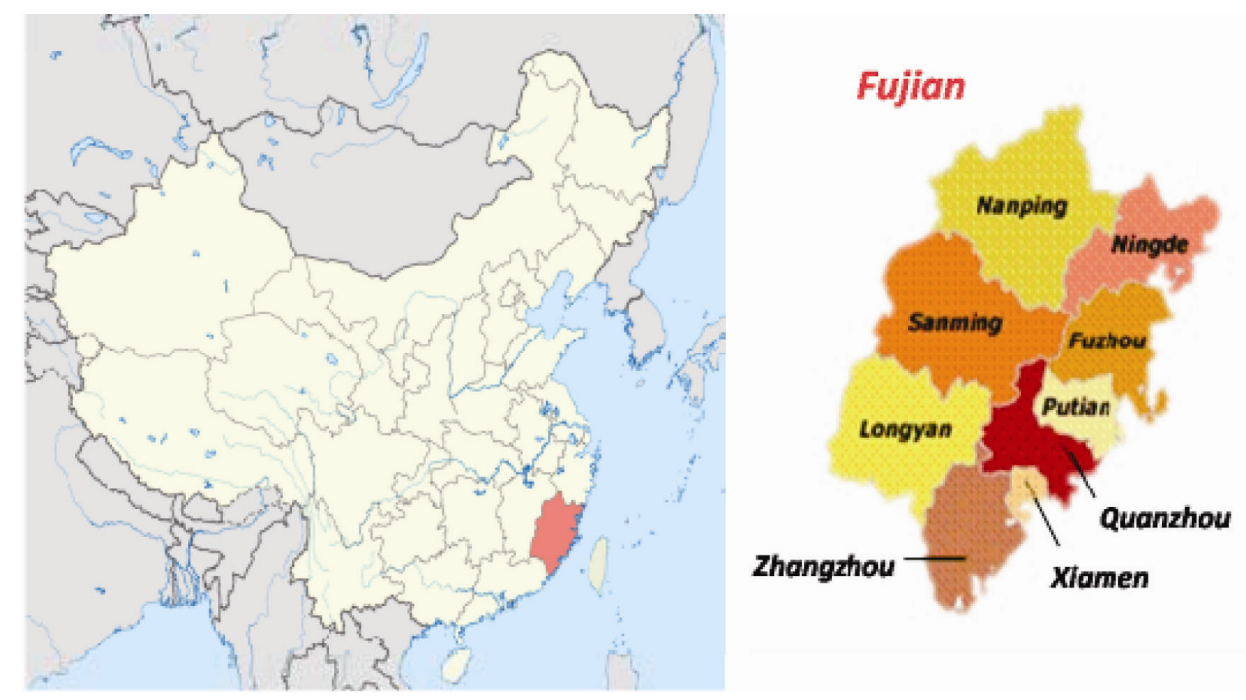

Figure 2. Location of sanming in Fujian and China

Source: http://www.sublet.com/images/city_images/China/Fujian.gif;

http://upload.wikimedia.org/wikipedia/commons/thumb/8/88/Fujian_locator_map_(China).svg/965px-Fujian_locator_map_(China).svg.png 
The forestry area of the whole prefecture is 1.89 million hectares, with a $76.8 \%$ of forest cover. Forest types range from subalpine forests, to cool temperate conifer forests, to broadleaved and pine mixed forest in sub-tropics. The growing stock is 115 million cubic meters, and bamboo forest reserves are 388 million stems - both ranking at the top of Fujian province. The output of main forestry products, such as timber, bamboo, artificial slab, resin, pulp and paper, accounts for one-quarter of Fujian province total. In 2010, forestry gross domestic product reached US $\$ 5.62$ billion, and the bamboo industry took up to $18.5 \%$ of it-again, the leading product in the Fujian province (Sanming Forestry Administration, 2010). Output of bamboo products has risen strongly. The region's historic strong involvement in trade continues, being adjacent to rapidly growing Guangdong region. Fuzhou's exports grew 18.4\% per year from 1991-2010 to reach US \$71 billion in 2010.

Sanming is also a typical collectively owned forest region. More than $80 \%$ of the woodland belongs to the rural collective and to individuals. Eighty percent of the population lives in the rural hilly area. Forestland area per capita is $11.6 \mathrm{mu}, 11$ times that of the farmland (Note 3). Therefore, income from forestry accounts for $23.2 \%$ of the total income for local farmers. In addition, Sanming has been an innovative leading pilot for the forest tenure reform all over the country since late 1980s (Sanming Forestry Administration, 1989). In contrast with other southern regions, Sanming did not participate in the previous reform in the early 1980s. The alternative path it explored, called shared-holding integrated forest tenure system (SHIFT) was to distribute the collective forests to individual households in the form of monetary shares rather than as distinct plots of forestland (Sun, 1992; Song et al., 1997; Liu, 2001). This arrangement was an innovation in Chinese community forestry and was then highly regarded for its ability to protect the tenure reform process and the forest resource (Song et al., 1997). Sanming prefecture was even granted the status of "Forest Reform Experimental Zone" due to its high concentration of shareholding systems, which accounted for $73.5 \%$ of its total forest land at the end of 1985 (Sanming Forestry Administration, 1988). Nevertheless, even the shareholding system allowed villagers only limited input to management decisions. It almost failed in two decades time with the absence of effective people's participation. Additionally, forest conservation became an increasingly difficult task for local forest authorities due to farmers' non-cooperation (Liu \& Edmunds, 2003; Chai, 2006).

In 1998, the newest phase began. Hongtian Village in Yongan County initially "privatized" forestland tenure, gradually followed by other villages since then. The essence of the reform is to dismantle the collective ownership system and to allocate parcels of forestland to individual farm households. In return, farmers pay a certain fee for the rights obtained (typically 10-40 yuan per mu per year). In this way, farmers enjoy significant freedom in managing their forest. Sanming officials recognized that mere distribution of certificates was not enough. They went one step further by creating new rules and institutions to improve the marketability of forestland rights and forest products. The number of transfers has grown considerably. As a result, a small number of farmers have now managed to lease or otherwise transfer large amounts of forestland by dealing with fellow farmers and forestry companies (Li \& Zhu, 2007).

Sanming has now completed registration of 1.7 million ha of the forest land rights, and issuing the usufruct certificates to the allocated households. Besides the liberalization of the timber market, 12 county-level and 79 township-level trade centers have been established -- the first regional forest property transaction network in China. They offer regular open auction, sales information and timber prices to buyer and seller, which make market more transparent. This creates the basic infrastructure for an actual property market. At the same time, Sanming has made available 4.65 billion (RMB yuan, around 0.72 billion US dollar) for forest property mortgages, providing needed financing options. Further, 942 forest farmer cooperatives (FFCs) have been founded, covering $67 \%$ of the total households. In contrast with previous collectively-owned forest, the new forest owners pool their resources in cooperatives, and design their own decision-making mechanisms. The individual owners have the right to decide whether they will, or will not, join the cooperative (Sanming Forestry Administration, 2011). The reform has led to a number of forest property types (Table 2). The liberalization of the market has attracted international interest. A large US forest products firm, Weyerhaeuser, holds a $49 \%$ joint venture interest in a forest property in Sanming. 
Table 2. Sanming's forest resources status in 2010

\begin{tabular}{llll}
\hline County & $\begin{array}{l}\text { Forest area } \\
\text { (thousands ha) }\end{array}$ & $\begin{array}{l}\text { Bamboo area } \\
\text { (thousands ha) }\end{array}$ & $\begin{array}{l}\text { Forest cover } \\
\text { (\%) }\end{array}$ \\
\hline Meilie & 27.28 & 4.09 & $80.3 \%$ \\
Sanyuan & 65.62 & 18.99 & $80.9 \%$ \\
Mingxi & 138.02 & 6.82 & $81 \%$ \\
Qingliu & 148.00 & 4.64 & $81.5 \%$ \\
Ninghua & 176.71 & 17.05 & $73.6 \%$ \\
Datian & 138.59 & 4.59 & $62.2 \%$ \\
Youxi & 249.91 & 26.25 & $73.2 \%$ \\
Shaxian & 137.82 & 24.91 & $76.6 \%$ \\
Jiangle & 188.89 & 27.91 & $84.1 \%$ \\
Taining & 114.74 & 13.77 & $75.1 \%$ \\
Jianning & 134.26 & 14.05 & $77.3 \%$ \\
Yongan & 243.83 & 42.85 & $82.5 \%$ \\
In total & 1763.67 & 205.93 & $76.8 \%$ \\
\hline
\end{tabular}

Source: Sanming Forestry Administration (2011).

Too many variables are involved to establish definitive causal relationship between the reform and the overall transformation of the forest sector. But it is clear that the market setting has changed profoundly and new trends have emerged, especially for the forest condition and environment conservation.

\section{Tenure Reform and Environmental Impacts}

Tenure does matter in China, affecting both the level of forest cover and the changes. The devolution polices of the early 1980s led to rapid harvest and loss of forest stock in most of the southern provinces. This was followed by a period of modest expansion in the late 1980s and faster growth since 1990s in reforestation and afforestation (Figure 3).

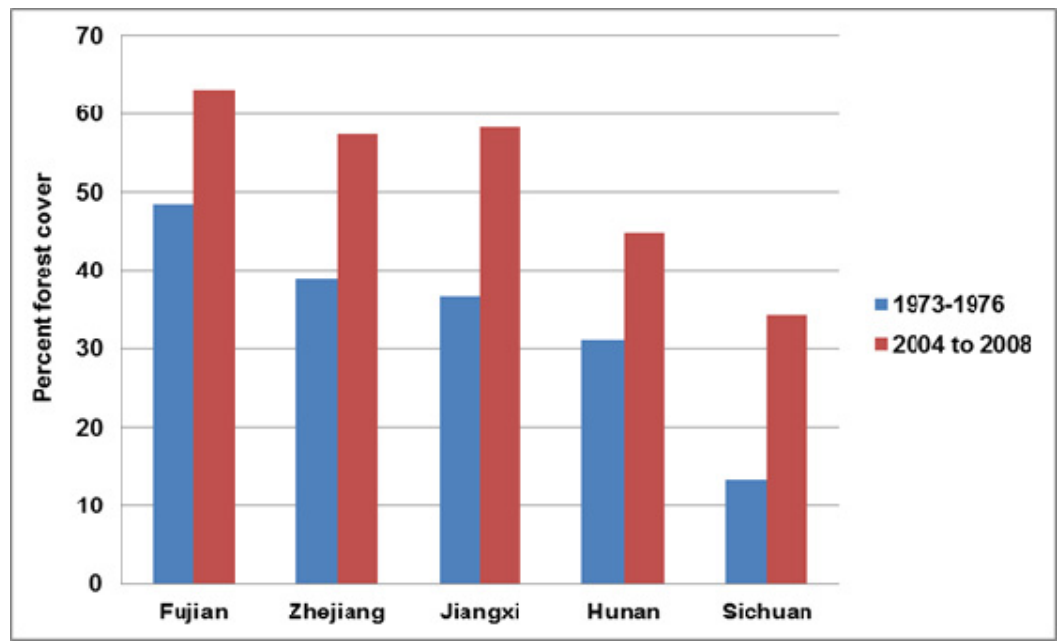

Figure 3. Forested area, five southern China provinces, 1973-2008

Source: China's forest inventory, Sanming Forestry Administration.

But the impact of reform on the environmental services of forests is ambiguous. Some scholars suggest that new plantations on previously denuded land improve environmental services (Liu \& Edmunds, 2003; Yin, 2003). Others argue that the decline in standing forest volume, especially in natural forest, combined with conversion to monoculture plantations, impair the ability of China's forests to provide biodiversity, natural habitat, pest resistance and carbon storage (Albers Rozelle \& Guo, 1998; Rozelle et al., 2003; Sayer \& Sun, 2003). Reform in Sanming provided an opportunity to examine the evolution of tenure system in collective forests and its environmental impacts. The following section will assess the impacts by decomposing them into three types: planted forest, bamboo, and natural forests. 


\subsection{Planted Forests}

Over many centuries, traditional practices emerged in parts of China for intensively managing tree plantings for fuel, construction, and local uses (Menzies, 1994). Over the first half of the $20^{\text {th }}$ century, institutional breakdown and warfare took a terrible toll on the forests. Since the late 1950s, China has experienced several periods of significant deforestation. Its links to soil erosion, loss of biodiversity, floods and other forms of environmental degradation have made protection of forest ecosystems a central government priority. Massive afforestation and reforestation efforts and land management/conservation have been made by central government through several projects such as National Afforestation Project in 1990 and the Forest Resource Development and Protection Project (FRDPP) in 1996. During the reform era, emphasis shifted to involving collective forest farms, shareholding forest farms and individual households, rather than state forest farms that were used exclusively in the earlier Forest Development Project (Turnbull, 2007). Additionally, relative to state farm managed forestland, collectives have done better in increasing forest area (Rozelle et al., 2003).

In Sanming, the government funding has supported up to $60 \%$ of afforestation expenses since late 1970s. From 1983 to 1992 , a total of 475,000 hectares of forest were planted. The SHIFT villages actively participated in afforestation since 1983, and became the leading contributors accounting for $71 \%$ of the total afforestation during this period. By 1995, 74\% of the 1,864 villages in Sanming Prefecture were managing 1.6 million ha of forested lands. Much of this land had been cut-over or degraded. The SHIFT system was credited with implementing quality reforestation, protecting forest regeneration and managing the growing resource (Song et al., 1997). Households at the time managed about $17 \%$ of the total planted area, while the state plantations accounted for $12 \%$ (Song, 1995).

SHIFT gradually collapsed in the 1990 s - by the year 2001, it was operating in only 59 of the 1,347 Sanming villages that had adopted SHIFT. In all instances where SHIFT boards were inactive, forest management decisions and tenure contracts were being administered by the village committees. New tenures such as household and Village Cluster management, firm-farmer partnership, as well as outsiders' lease contract arose (Song et al., 2004). In the new round of tenure reform, these updated tenure types led to increased efficiency in conducting needed forestry operations and private investment in afforestation and reforestation (Table 3). Especially since 2003 the proportion of nonstate afforestation increased from 22\% to 64\% (Sanming Forestry Administration, 2003-2010).

Besides improved tenure arrangements, market, fiscal and financial policy activities are important drivers to forest condition changes. Before long, it was recognized that taxes and charges for harvesting were excessive and posed a barrier to investment. These charges were reduced. Responding to lower taxes, the liberalized market mechanism and newly available discounted mortgage financing, more afforestation has been conducted, especially the timber plantation and economic forest crops (primarily orchards) (Table 3). On the other hand, lower taxes and charges make harvesting more profitable. These changes hastened the rate of conversion of natural environments and increased the loss of environmental services (Liu \& Landell-Mills, 2003).

Table 3. Sanming afforestation (Unit: ha)

\begin{tabular}{llllllll}
\hline Year & Afforestation & $\begin{array}{l}\text { Natural forest } \\
\text { restoration }\end{array}$ & $\begin{array}{l}\text { Timber } \\
\text { plantation }\end{array}$ & $\begin{array}{l}\text { Commercial } \\
\text { tree crops }\end{array}$ & State & $\begin{array}{l}\text { Non-state } \\
\text { Bamboo } \\
\text { plantation area }\end{array}$ \\
\hline 2001 & 13,869 & 1,927 & 12,007 & 1,862 & 5,271 & 2,765 & 873 \\
2002 & 13,496 & 1,728 & 12,263 & 1,233 & 5,501 & 2,932 & 780 \\
2003 & 11,550 & 1,175 & 10,438 & 1,112 & 8,958 & 2,591 & 846 \\
2004 & 16,166 & 1,099 & 15,112 & 775 & 10,977 & 5,191 & 405 \\
2005 & 24,851 & 3,508 & 17,960 & 731 & 8,379 & 10,465 & 565 \\
2006 & 24,671 & 3,658 & 18,066 & 738 & 6,709 & 12,309 & 596 \\
2007 & 27,382 & 3,224 & 20,293 & 755 & 6,802 & 14,249 & 499 \\
2008 & 31,377 & 2,473 & 25,277 & 853 & 8,821 & 17,310 & 322 \\
2009 & 35,688 & 3,413 & 29,287 & 1,066 & 10,607 & 19,746 & 129 \\
2010 & 25,308 & 5,938 & 22,964 & 1,898 & 9,026 & 16,282 & 197 \\
\hline
\end{tabular}

Source: Sanming Forestry Administration (1999-2010).

Accelerated roading and harvesting in steep regions has increased potential for erosion. For example, in order to combat erosion, maximize water yield and regulate seasonal flows of Min River, shelterbelts have been a key 
component of forest cover. Annual afforestation efforts almost doubled during the past ten years (Sanming Forestry Administration, 2010), which has enhanced water availability for agriculture, industrial and domestic uses, as well as for preventing floods in downstream areas (Pan, 2006).

The expansion of monocultural plantations was another consequence of devolution. When mixed-species natural forests were harvested, they were often replaced with large-scale plantations of the fast growing species such as Chinese fir, Masson pine and bamboo (Zhang et al., 2010). The dominance of planted species reduced overall landscape diversity. Management was unlikely to respond to broader forest based environmental values (Liu \& Edmunds, 2003). In Sanming, Pan (2006) has estimated that newly afforested monoculture managed stands exhibited lower amount of desirable soil nutrients and soil qualities, including: soil porosity, aeration, and bulk density, compared to mature mixed-species natural forests. Further, soil water storage capacity of natural broadleaf exceeds that of fir plantations; average water-holding capacity of mixed-species plantations is, in turn, higher than that of monoculture bamboo plantation.

\subsection{Bamboo: Friend in Winter}

In ancient China bamboo was a feature of daily life. It was used for food, clothing, housing and transportation. China's first books were crafted from bamboo strips strung on string, and almost all ancient musical instruments were made of bamboo. Paintbrushes made from bamboo are used today.

Bamboo is viewed as a symbol of traditional Chinese values. It is an example of the harmony between nature and human being. Chinese ancients designated the plum, orchid, bamboo and chrysanthemum as "four gentlemen", and pine, bamboo and plum as the "three friends in winter." People think its deep root denotes resoluteness; its tall, straight stem represents honorability; its hollow interior represents modesty; and its clean and spartan exterior exemplifies chastity. Ancient Chinese literati held bamboo in high esteem; many writings and paintings depict it throughout history.

Commercial bamboo forests face the fewest restrictions on harvest and use. Increasing demand and economic returns spurred the Chinese bamboo sector to a steady rise over the last 50 years. Bamboo has become increasingly important in terms of both the forested area and market share within the forest industry. Moso bamboo now covers roughly 5 million hectares nationwide (Lou \& Henley, 2010). Bamboo area in Sanming now reaches 280,000 ha. Production of bamboo products has resin strongly (Figure 4).

Bamboo stands are very dense. Light reaching the forest floor is low. Bamboo leaf litter is a harsh substrate for many other kinds of plants, so little understory vegetation is found in the plantations. Some owners retain legacy broadleaf trees for their ecosystem value where they are present. Effects of these changes on wildlife habitat have not, to our knowledge, been directly studied in this area.

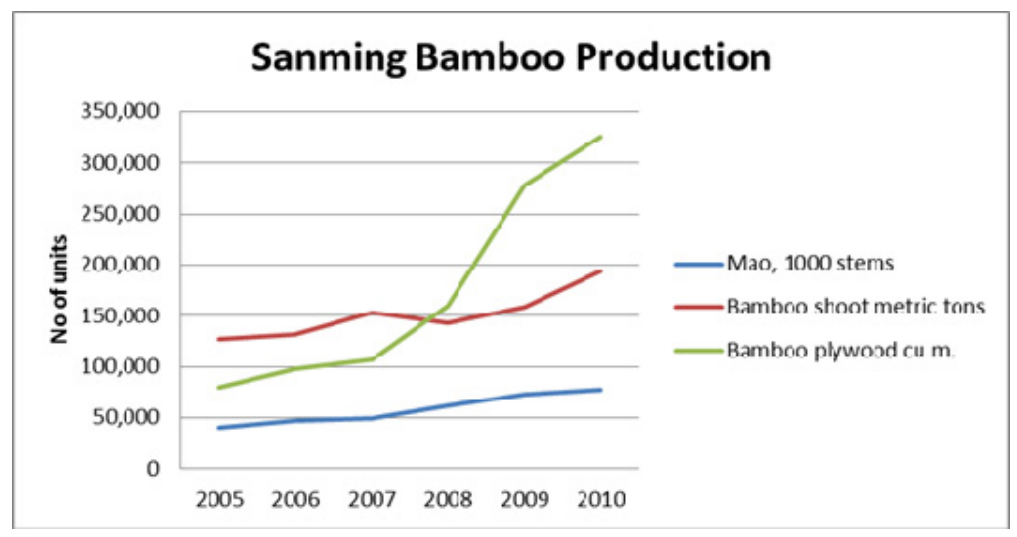

Figure 4. Sanming bamboo production in 2005-2010

Source: Sanming Forestry Administration (2005-2010).

During the tenure reform, bamboo plantations in Sanming expanded steadily. Reduced biodiversity in bamboo forests is thought to negatively affect both site quality and resilience of stands to disease, pests, and adverse weather events (Lou \& Henley, 2010). In the severe snowstorms which hit south China in 1999 and 2007, the bamboo monocultures suffered the most severe damage - crown decapitation, stem breakage, branch snapping, bending, and uprooting, amounting to 0.23 million hectares. The loss was estimated at US \$0.59 billion in 2007 . 
The damage to forests led to secondary hazards. Soil erosion and landslides increased. The sudden increase in wounded trees resulted in insect infestation and disease. Accumulations of dead litter on forest floors provided fuel for fires. Forest fires increased substantially in subsequent months. For example, the number of forest fires in 2000 and 2008 was almost 5 and 3 times higher respectively than the previous year, and the burned area was 3 times higher than the average (Table 4).

Table 4. Sanming's forest fire experience, 1999-2010

\begin{tabular}{|c|c|c|c|c|c|c|}
\hline \multirow{2}{*}{ Year } & \multicolumn{2}{|c|}{ Number of Fires } & \multirow{2}{*}{$\begin{array}{l}\text { Burned area } \\
\text { (ha) }\end{array}$} & \multirow{2}{*}{$\begin{array}{l}\text { Affected area } \\
\text { (ha) }\end{array}$} & \multirow{2}{*}{$\begin{array}{l}\text { Forest loss } \\
\text { Volume }\left(\mathrm{m}^{3}\right)\end{array}$} & \multirow{2}{*}{$\begin{array}{l}\text { Economic Loss } \\
\text { (million US\$) }\end{array}$} \\
\hline & Total & Major & & & & \\
\hline 1999 & 22 & & 154.4 & 110.8 & 4,001 & 0.15 \\
\hline 2000 & 124 & 3 & $2,527.9$ & $1,818.1$ & 49,285 & 2.47 \\
\hline 2001 & 35 & & 219.6 & 152.5 & 2,329 & 0.21 \\
\hline 2002 & 62 & & 586 & 355.3 & 7,968 & 0.48 \\
\hline 2003 & 85 & & 665.3 & 461.6 & 12,862 & 0.63 \\
\hline 2004 & 135 & & $1,597.8$ & $1,106.7$ & 37,302 & 1.50 \\
\hline 2005 & 20 & 14 & 186.3 & 95.2 & 4,235 & 0.13 \\
\hline 2006 & 15 & 9 & 102.2 & 88.2 & 3,941 & 0.12 \\
\hline 2007 & 42 & 32 & 357 & 257.1 & 12,421 & 0.38 \\
\hline 2008 & 116 & 94 & $2,319.4$ & $1,963.8$ & 90,422 & 3.18 \\
\hline 2009 & 160 & 147 & $3,861.4$ & $3,138.9$ & 135,798 & 5.17 \\
\hline 2010 & 27 & 25 & 372 & 312.6 & 17,110 & 0.52 \\
\hline
\end{tabular}

Source: Sanming Forestry Administration (2009).

The damage to the country's burgeoning forestry program was of particular concern because of the scale and potential long-term consequences. Central and southern China has been undergoing intensive afforestation and reforestation since the 1980s. With such severe large-scale damage, the region's forests will likely act as carbon sources for years to come. Before the storm, forests in this region accounted for $65 \%$ of the regional terrestrial carbon sink and much of this sink was due to plantations (Piao et al., 2009). Further research on this issue is needed (Zhou et al., 2011).

\subsection{Natural Forests}

Damage from natural hazards drew attention to environmental issues relating to deforestation. The devastating flooding along major rivers in 1998 led to striking state actions. In 1998, the central government sharply curtailed commercial harvesting in western and northern areas of the country. Although initially focused on public forests, the policy was soon extended to collective forests, covering almost 27 million hectares of collectively owned land by 2003 . The government also initiated a classification-based forest management system in the mid-1990s, which reclassified the forest into two categories: ecological forests (consisting of former shelter forests and forests for special use), and commercial forests (comprising former timber forests, economic forests, and fuelwood forests). Regulations on management, funding and exploitation are different for these two categories of forests. Commercial forests basically follow market rules, while ecological forests remain mostly funded by the government. The classification-based management policy was reinforced in early 2000 with the establishment of the category "public benefit forest" where no commercial harvesting was allowed and the simultaneous implement of the "Forest Ecosystem Compensation Program" (FECP) - a public program designed to compensate forest owners for income lost due to the logging ban (Xu White and Lele 2010).

There are 1.08 million hectares of natural forests existing in Sanming, accounting for $73.8 \%$ of total forest land. However, natural forest in Sanming has been heavily exploited, and was largely composed of degraded or sparse and inaccessible natural forest. Among them, 0.48 million hectare has been designated for public ecosystem conservation, the others are commercial timber forests. Steps have been taken to improve farmer incentives for recognizing environmental issues. During the forest tenure reform, households and local farmers gained more opportunities for direct participation and management (Dan 2012). Since 2000, the annual natural forests restoration area has risen sharply from 961 ha in 2000 to 5937.8 ha in 2010. Meanwhile, the logging ban in natural forest has been relaxed, allowing for selective harvest and restricted use (Figure 5). 


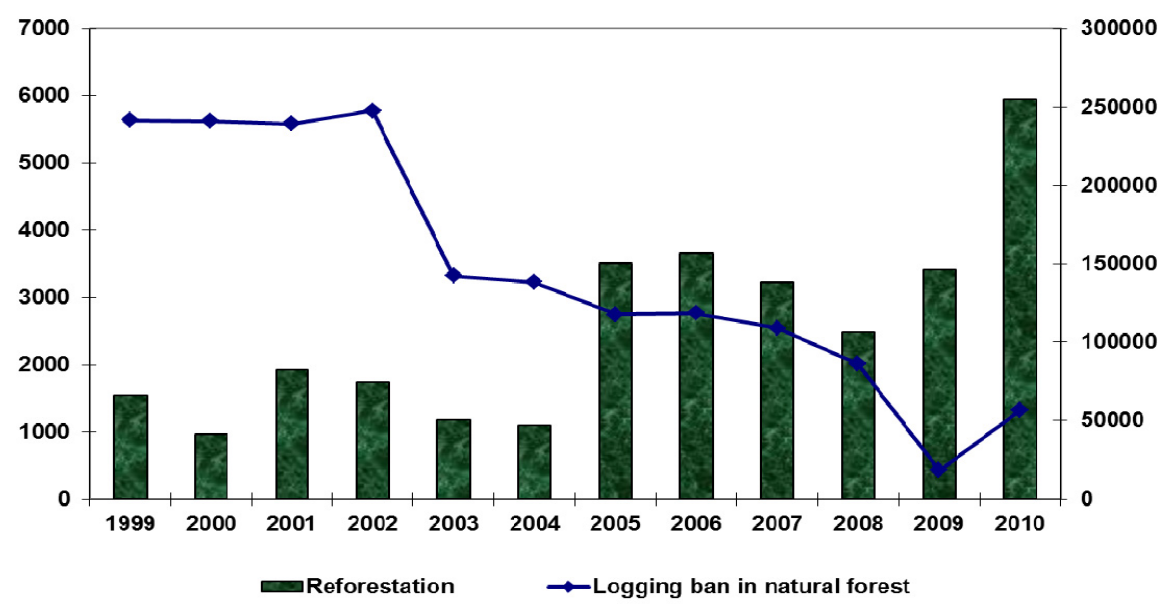

Figure 5. Reforestation area and area covered by logging ban in Fujian, 1999-2010

Source: Sanming Forestry Yearbook, 1999-2010.

The forest tenure reform created new room for developing market-based voluntary payments for environmental services (PES) in China. To complement low compensation from state and provincial government, new ecological compensation charges for environmental services such as forest recreation and downstream protection against flooding and sedimentation in Sha County and Yongxi County were imposed to compensate the private forestland users. Funds were authorized for a county-level forest ecological benefit compensation fund. Yongan city charges 0.001 dollar/ton of water supply, $1.54 \mathrm{dollar} / \mathrm{m}^{3}$ of timber harvest fee, $8 \%$ of forest tourism revenue and 0.005 yuan/wa (equivalent to $0.07 \mathrm{cent} / \mathrm{wa}$ ) extra electricity fee to collect US $\$ 0.15$ million as ecological compensation annually. County-level funds increased the level of state and provincial compensation to forest rights holders by 2 yuan/mu ( 0.02 dollar/hectare) on average. Overall, the evolving payment scheme mechanism is also a part of process of transformation from formal, centralized and governmental agents to an informal, decentralized and horizontal governance structure.

\subsection{Reserves}

To provide environmental services such as habitat for threatened and endangered species, 11 national and provincial level nature forest and wildlife reserves have been established in Sanming prefecture, amounting to 80,317 hectares (Table 5). In addition, 1,060 county level nature reserves protect 96,150 hectare land. Besides that, Sanming has 6 national and 14 provincial level forest parks, ranking highest in the Fujian province. They all together effectively preserve $70 \%$ of typical forest ecosystem and $80 \%$ of wild animals (Sanming Forestry Administration 2008).

Table 5. Sanming's forest resources (Unit: ha)

\begin{tabular}{lllllll}
\hline Total area & $\begin{array}{l}\text { Total forest } \\
\text { area }\end{array}$ & $\begin{array}{l}\text { Commercial } \\
\text { timber forest }\end{array}$ & $\begin{array}{l}\text { Ecological } \\
\text { benefit forest }\end{array}$ & $\begin{array}{l}\text { Maso } \\
\text { bamboo }\end{array}$ & $\begin{array}{l}\text { Economic forest (tea } \\
\text { and orchid) }\end{array}$ & $\begin{array}{l}\text { Natural } \\
\text { forest }\end{array}$ \\
\hline $2,290,000$ & $1,763,667$ & $1,399,467$ & 476,000 & 203,467 & 95,467 & $1,080,000$ \\
\hline & $79.30 \%$ & $26.90 \%$ & $11.50 \%$ & $5.40 \%$ & $61.24 \%$ \\
\hline
\end{tabular}

Source: Sanming Forestry Yearbook (2010).

Note: The forest types mentioned above have overlapped the part. The total weight is larger than $100 \%$. For example, most of maso bamboo is regarded as timber forest.

1) Over a decade ago, China began zoning its forests according to their ecological or productive potential and on this basis determining types of management (Specialized Forest Management). The Ecological Compensation scheme applies to "protection forests" (forests located in the upper catchments and along riverbanks of important rivers, natural forests in dry regions, and logged over degraded lands in mountainous areas) and "special-use forests" (nature reserves, heritage forests), designated as "ecological benefit forests"; Most of this is natural forest but natural forest is far larger than it. 
2) Economic forests are forest for non-timber products, including Fruit forest, Oil crops forest, chemical, materials forest, Medicinal forest Flavor seasoning forest.

3) Most of bamboo forest is included in timber forest.

Another set of environmental effects are from substitution of wood supply. The logging ban reduced the domestic supply of legally harvested wood available to wood-processing industries, forcing domestic industries to import logs and sawn wood from other countries. Furthermore, the high prices for logs have increased illegal logging in China and other tropical countries (Zhang Buongiorno \& Zhu, 2012). This reliance on imports has created a negative image of China as a destroyer of global forest resources and environmental services. However, the tenure reform on collective forests did mitigate China's timber shortage by large scale afforestation and reforestation.

\subsection{Perceptions of Reform Impacts—Local People's Perceptions}

In China's northern plains, planted trees produce almost immediate benefits in the form of erosion control and improved soil conditions. This could be reflected promptly in measurable increases in agricultural productivity (Yin, 2003). But in hilly Fujian, the range of local environmental impact is both broad and difficult to measure. Considering the proximity of environmental impacts to human populations, one way pursue this is to interview local people to obtain their perceptions of the tenure reform's impact on environmental services. Zhang, Buongiorno and Zhu (2012) previously conducted a large-scale survey to assess how the environmental impacts of tenure reform are perceived by a local population and which factors affect the relationship between impacts and perceptions' formation.

In July-August of 2011, personal household questionnaires were directed to a randomly selected sample among rural resident families across a wide geographic area with nine provinces, including Jiangxi, Fujian, Liaoning, Shandong, Gansu, Henan, Zhejiang, Shan'xi and Beijing. Altogether, 2,480 usable questionnaires were collected (response rate of $88.6 \%$ ) for a total of 2,800 questionnaires. The questionnaire consisted of 9 questions, including questions about the socio-demographic profile of the household interviewed, attitude changes towards tenure reform, and perceptions about the environmental impacts. In his paper, Dr Zhang el at first applied Multidimensional Scaling (MDS) to understand the connectivity among people's perception about tenure reform and its environmental impacts. In this case, the output is a plot of 9 points standing for each component in a two-dimensional graph. The points are positioned so that the distances between them reflect as closely as possible the dissimilarities between the entities. In general, annual income, education, gender, age, job, attitude towards reform and investment after reform are connected to the impacts on biodiversity, soil protection, air purification, carbon sequestration, forest tourism and water resource conservation. And various distance indicated different level of connectivity, among them the investment into forest management is most closely connected to environmental impacts. Furthermore, the optimal scaling regression results indicate that investment in forestry has most significant impact on forest biodiversity, and the following are job identity and attitude toward reform. Perceptions on environment were also affected by the attitudes of forest farmers, family income level, educational level and gender.

In Sanming, among 269 sampled households, the majority stated that they are satisfied with the performance of tenure reform (Table 6). Table 6 shows the perception of respondents towards environmental impacts, listing the effect level scored by the statements included in the questionnaire. No negative impacts were perceived by respondents, and most acknowledge the improvement to various degrees. Moreover, enhanced management due to tenure reform is seen as contributing contributes to improved environmental services. Perceptions of local people are useful to learn, but obviously more quantitative and repeatable measures are need in the future. 
Table 6. Perceptions of bamboo growers in sanming

\begin{tabular}{|c|c|c|c|}
\hline & Level of impacts & Households & Proportion \% \\
\hline \multirow{3}{*}{ Satisfaction towards tenure reform } & Satisfied & 210 & 78.1 \\
\hline & Not satisfied & 33 & 12.3 \\
\hline & Others & 26 & 9.7 \\
\hline \multirow{5}{*}{ Biodiversity } & Deteriorated & 0 & 0.0 \\
\hline & No Change & 94 & 34.9 \\
\hline & Improved a little & 140 & 52.0 \\
\hline & Improved moderately & 21 & 7.8 \\
\hline & Improved very much & 14 & 5.2 \\
\hline \multirow{5}{*}{ Soil conservation } & Deteriorated & 0 & 0.0 \\
\hline & No Change & 78 & 29.0 \\
\hline & Improved a little & 140 & 52.0 \\
\hline & Improved moderately & 17 & 6.3 \\
\hline & Improved very much & 34 & 12.6 \\
\hline \multirow{5}{*}{ Air quality } & Deteriorated & 0 & 0.0 \\
\hline & No Change & 110 & 40.9 \\
\hline & Improved a little & 140 & 52.0 \\
\hline & Improved & 0 & 0.0 \\
\hline & Improved very much & 19 & 7.1 \\
\hline \multirow{5}{*}{ Carbon storage } & Deteriorated & 0 & 0.0 \\
\hline & No Change & 92 & 34.2 \\
\hline & Improved a little & 99 & 36.8 \\
\hline & Improved moderately & 32 & 11.9 \\
\hline & Improved very much & 46 & 17.1 \\
\hline \multirow{5}{*}{ Forest tourism } & Declined & 0 & 0.0 \\
\hline & No Change & 109 & 40.5 \\
\hline & Increase a little & 100 & 37.2 \\
\hline & Increase moderately & 23 & 8.6 \\
\hline & Increase very much & 37 & 13.8 \\
\hline \multirow{5}{*}{ Water origin conservation } & Deteriorated & 0 & 0.0 \\
\hline & No Change & 78 & 29.0 \\
\hline & Improved a little & 99 & 36.8 \\
\hline & Improved moderately & 58 & 21.6 \\
\hline & Improved very much & 34 & 12.6 \\
\hline
\end{tabular}

Source: Zhang Ying et al. (2012).

\section{4. "A Land of Bamboo Groves": Conclusions}

Growing and competing demands for food, biofuels, timber, and environmental services have posed severe challenges to effective forest governance in rural China, especially considering the direct and indirect impacts of climate change. Understanding the complexity of effects on the forest environments generated by three decades' tenure reform in Sanming is a crucial step toward improving China and other countries' future forestry policies.

Sanming's forest tenure reform coincides with a general trend of forestry decentralization in China's collectively-owned forest areas, aiming for better rural livelihood and sustainable development. Meaningful conservation can be expected only when a community is given property rights to the forests and thus rights to extraction from the ecosystem they conserve (Hazra, 2002). In a sense, Sanming's reform is a step ahead of this mainstream movement. The reform has been implemented as part of a broad reform agenda supported by related forest policy, legislation and institutional arrangements. In particular, tenure reform has been embedded within the overall sustainable development agenda of the region.

The reform of forest tenure in Sanming is a learning process and evolving experiment. Despite occasional setbacks and inconsistencies, the reform has so far created a more effective framework for forest governance and sustainable management. Although the flexibility to respond to local differences is desirable, frequent policy experimentation creates uncertainty and can impose significant environmental and social costs. The Sanming experience clearly shows that simply issuing land rights certificates is not enough. Sanming illustrates a major social change in forested regions of southern China - the creation, in quite a short time, of entirely new property rights institutions and relationships. We may expect further changes as experience accumulates. Interviews with 
farmers who have receive land rights, and local officials, indicate a high degree of satisfaction with the opportunities created by the rights reforms. An emerging concern, however, will be to ensure that the pace of change is well calibrated so that it does not become disruptive to future investment, management, and investment in processing.

The overall trend of ecological/environmental health in China, represented by improvement in some regions but deterioration in the country as a whole, has not as yet been decisively reversed. The rapid expansion of planted forests and economic forests certainly exert far-reaching influences on the environment. But monitoring of cumulative environmental impacts has not been carried out comprehensively, especially at the landscape scale. One reason for the disconnection between rapid land use change and minimal focus on impact assessment is the absence in China of traditions of hunting (Note 4) and fishing by individual citizens. Explaining this fact would require a social history of China, but one result is that there is no broad-based citizen constituency for fish and game conservation, nor are there strong national and regional NGO's focused on the issue. As a result, there is little focus on these issues in the country's environmental institutions. There is no lack of ecological and environmental research in China, but it has generally been directed to other problems perceived to be more pressing.

Additionally, the evaluation of payments for environmental services should focus on the impact they have in changing the behavior of forest users and other stakeholders as well as the quality of forest ecosystem services. The net environmental impact is not yet clear. Prevailing project-based methods of environmental impact assessment (EIA) alone cannot deal with the cumulative effects induced by interaction among different reform policies within an area ( $\mathrm{Li}$ Wang \& Liu, 1998). Besides transplanting conventional EIA methods, a new integrated quantitative assessment approach in which addresses human society, the economy and natural environment as components of an interrelated system is needed.

\section{Acknowledgements}

The authors are grateful for helpful comments and useful suggestions from Prof Shashi Kant in University of Toronto, Prof. Wen Yali, Prof. Li Hongxun and Dr Xie Yi in Beijing Forestry University. We appreciated the assistance of the following officers in Sanming Forestry Administration who dedicated their time and support for our field trip and data collection: Pan Zifan, Lin Jianfeng, Lin Zhenbin, Wang Naiwei and Lin Guoqing. We are also thankful to Dr. Song Yajie for his intellectual direction and inspiration. The phrase "Land of Bamboo groves" is a quote from Bai Juyi, a Tang dynasty poet and official.

\section{References}

Albers, H. J., Rozelle, S. D., \& Guo, L. (1998). China's forests under economic reform: timber supplies, environmental protection, and rural resource access. Contemp Econ Policy, 16, 22-33. http://dx.doi.org/10.1111/j.1465-7287.1998.tb00497.x

Biaozhi, P. (2006). Grade evaluation of ecological forests of Sanming City as to their water conservation function. J Cent South For Univ., 26, 33-42.

Blaikie, P. M., \& Muldavin, J. S. S. (2004). Upstream, downstream, China, India: the politics of environment in the Himalayan region. Annals Assoc Am Geogr, 94, 520-548. http://dx.doi.org/10.1111/j.1467-8306.2004.00412.x

Chai, X. T. (2006). Collective forest tenure reform in Fujian. Paper presented at the International Workshop on Forest Tenure Reform, September 21, 2006, Beijing.

Elvin, M. (2006). Retreat of the elephants: an environmental history of China. New Haven: Yale University Press.

Fang, J. Chen, A., Peng, C., Zhao, S., \& Ci, L. (2001). Changes in forest biomass carbon storage in China between 1949 and 1998. Science, 292, 2320-2322. http://dx.doi.org/10.1126/science.1058629

FAO. (2010). Global Forest Resources Assessment 2010 Country report-China. Forestry Department, Food and Agriculture Organization of the United Nations. Rome. Retrieved from http://www.fao.org/forestry/fra/fra2010/en/

Hazra, A. K. (2002). History of Conflict over Forests in India: A Market Based Resolution. Working Paper Series, Julian L. Simon Center for Policy Research. New Delhi, India.

Hyde, W. F., Belcher, B., \& Xu, J. T. (Eds). (2003). China's forests: global lessons from market reforms. Resource for the Future, Washington, DC. 
Li, P., \& Zhu, K. L. (2007). A legal review and analysis of China's forest tenure system with an emphasis on collective forestland. Rights and Resources Initiative, Rural Development Institute.

Li, W., Wang, H., \& Liu, D. X. (1998). Progress of environmental impact assessment and its methods in China. In A. Porter \& J. Fittipaldi (Eds.), Environmental Methods Review: Retooling Impact Assessment for the New Century (pp. 50-57). Army Environmental Policy Institute and International Association for Impact Assessment, Atlanta and Fargo.

Liang, D. (2012). Payment schemes for forest ecosystem services in China: policy, practices and performance. Wageningen Academic Publishers. Environmental Policy Series, 5, 214.

Liu, D. (2001). Tenure and management of non-state forests in China since 1950: A historical review. Environ Hist, 6, 239-263. http://dx.doi.org/10.2307/3985086

Liu, D., \& Edmunds, D. (2003). Devolution as a means of expanding local forest management in South China. In W. F. Hyde, B. Belcher, \& X. Jintao (Eds.), China's Forests: Global Lessons from Market Reforms (pp. 27-58). Resources for the Future and CIFOR, Washington, DC and Bogor, Indonesia.

Liu, J. (2009). Implications and challenges of decentralized China's collective forest management. Paper presented at XIII World Forestry Congress, Buenos Aires.

Liu, J. G., Li, S. X., Ouyang, Z. Y., Tam, C., \& Chen, X. D. (2008). Ecological and socioeconomic effects of China's policies for ecosystem services. Proceedings of the National Academy of Sciences of the United States of America, 105(28), 9477-9482. http://dx.doi.org/10.1073/pnas.0706436105

Liu, J. L. (2006). Forests in the mist. Ph.D. thesis. Wageningen, the Netherlands, Wageningen University.

Liu, J., \& Landell-Mills, N. (2003). Taxes and fees in the southern collective forest region. In W. F. Hyde, B. Belcher, \& X. Jintao (Eds.), China's Forests: Global Lessons from Market Reforms. Resources for the Future and CIFOR, Washington, DC and Bogor, Indonesia.

Lou, Y. P., \& Henley, G. (2010). Biodiversity in bamboo forests: a policy perspective for long term sustainability. International Network for Bamboo and Rattan (INBAR), Beijing, China.

Lu, J., \& Zhang, Y. (2012). Study of environmental impact of forest tenure reform in Suichuan, Jiangxi Province based on Logit model. Environ and Sustainable Dev., 37(2).

Menzies, N. K. (1994). Forest and Land Management in Imperial China. Ford Foundation, Beijing. St martin's press.

Perry, D. A., Oren, R., \& Hart, S. C. (2008). Forest ecosystems (2nd ed.). Baltimore, MD: Johns Hopkins University Press.

Piao, S., Fang, J., Ciais, P., Peylin, P., Huang, Y., Sitch, S., \& Wang, T. (2009). The carbon balance of terrestrial ecosystems in China. Nature, 458, 1009-1013. http://dx.doi.org/10.1038/nature07944

Pomeranz, K. (2000). The great divergence: China, Europe, and the making of the modern world economy. Princeton, NJ: Princeton University Press.

Property Rights Law of People's Republic of China. (2007). National People's Congress, Beijing, China. Retrieved from http://www.lawinfochina.com/Display.aspx?lib=law\&ID=6642

Rozelle, S., Huang, J. K., \& Benziger, V. (2003). Forest exploitation and protection in reform China: assessing the impacts of policy and economic growth. In W. F. Hyde, B. Belcher, \& X. Jintao (Eds.), China's Forests: Global Lessons from Market Reforms. Resources for the Future and CIFOR, Washington, DC and Bogor, Indonesia.

Rudel, T. K., Coomes, O. T., Moran, E., Achard, F., Angelsen, A., Xu, J., \& Lambin, E. (2005). Forest transitions: towards a global understanding of land use change. Global Environ Change, 115, 23-31. http://dx.doi.org/10.1016/j.gloenvcha.2004.11.001

Rural Land Contracting Law of People's Republic of China. (2002). National People's Congress, Beiijing, China. Retrieved from http://english.gov.cn/laws/2005-10/09/content_75300.htm

Sadler, B., \& Verheem, R. (1996). Strategic environmental assessment: status, challenges and future directions (Vol. 53). Ministry of Housing, Spatial Planning and the Environment of the Netherlands.

Sanming Forestry Administration. (2008). Two decades of forest tenure reform in Sanming. Beijing, China: China Forestry Press. 
Sanming Forestry Administration. Sanming Forestry Yearbook, 1988-1989; 1999-2010.

Sayer \& Sun. (2003). Impacts of policy reforms on forestry environments and biodiversity. In W. F. Hyde, B. Belcher, \& X. Jintao (Eds.), China's Forests: Global Lessons from Market Reforms (pp. 177-194). Resources for the Future and CIFOR, Washington, DC and Bogor, Indonesia.

Song, Y. J. (1995). Shareholding integrated forestry tenures: a case from South China. Ann Arbor, MI: University Microfilms International.

Song, Y., Burch, W. Jr., Geballe, G., \& Liping, G. (1997). New organizational strategy for managing the forests of southeast China: the shareholding integrated forest tenure (SHIFT) system. For Ecol Manag, 9(1), 183-194.

Song, Y., Wang, G., Burch, W. R. Jr., \& Rechlin, M. A. (2004). From innovation to adaptation-lessons from twenty years of SHIFT forest management system in Sanming, China. For Ecol Manag, 191, 225-238.

Songster, E. E. (2003). Cultivating the nation in Fujian's forest: forest policies and afforestation efforts in China, 1911-1937. Environ Hist, 8, 452-473. http://dx.doi.org/10.2307/3986204

State Forestry Administration. (1989). China's forestry statistic yearbook. Beijing, China: China Forestry Press.

State Forestry Administration. (2010). A summary of China's current forest resource conditions. Beijing, China: China Forestry Press.

Sun, C. J. (1992). Community Forestry in Southern China. J For., 90(6), 35-39.

Therivel, R., Wilson, E., Thompson, S., Heaney, D., \& Pritchard, D. (1994). Strategic environmental assessment. London, England: Earthscan Publications Ltd.

Turnbull, J. W. (2007). Development of sustainable forestry plantations in China: a review. Impact Assessment Series Report, No. 45.

Wang, X. L. (2006). Comparative analysis and policy recommendations on developing bamboo tenure systems in Asia and Africa. INBAR and World Forestry Center, Portland OR.

Xiao, X. W. (2005). Atlas of the Forest Resources of China. Beijing, China: China Forestry Press.

$\mathrm{Xu}$, J. C., \& Melick, D. R. (2007). Rethinking the effectiveness of public protected areas in southwestern China. Conservation Biol., 21(2), 318-328. http://dx.doi.org/10.1111/j.1523-1739.2006.00636.x

$\mathrm{Xu}, \mathrm{J}$. T. (2010). Collective forest tenure reform in China: what has been achieved so far? Paper presented at World Bank Conference on Land Governance. World Bank, Washington, DC.

Xu, J. T., White, T. A., \& Lele, U. (2010). China's forest land tenure reforms: impacts and implications for choice, conservation, and climate change. Rights and Resources Initiative, Washington, DC.

Xu, J., Yang, Y., Fox, J., \& Yang, X. (2007). Forest transition, its causes and environmental consequences: empirical evidence from Yunnan of Southwest China. Tropical Ecology, 48(2), 137-150.

Yin, R. S., \& Newman, D. H. (1997). The Impact of Rural Reform on China's Forestry Development. Environ and Dev Econ, 2(3), 289-303. http://dx.doi.org/10.1017/S1355770X97000041

Yin, R. S., Xu, J. T., \& Li, Z. (2003). Building Institutions for Markets: Experience and Lessons from China's Rural Forest Sector. Environ, Dev and Sustainability, 5, 333-351. http://dx.doi.org/10.1023/A:1025768727924

Yin, R. S., Yao, S. B., \& Huo, X. X. (2013). China's forest tenure reform and institutional change in the new century: What has been implemented and what remains to be pursued? Land Use Policy, 30, 825-833. http://dx.doi.org/10.1016/j.landusepol.2012.06.010

Zhang, H., Buongiorno, J., \& Zhu, S. (2012). Domestic and foreign consequences of China's land tenure reform on collective forests. Int For Rev., 14(3), 349-362.

Zhang, P. C., Shao, G. F., Zhao, G., Master, D. C. L., Parker, G. R., \& Dunning, J. B. (2000). China's forest policy for the $21^{\text {st }}$ century. Science, $288,2135-2136$. http://dx.doi.org/10.1126/science.288.5474.2135

Zhang, Y., Irland, L. C., Zhou, V., Song, Y., Wen, Y., \& Liu, J. (2010). Plantation development: economic analysis of forest management in Fujian Province, China. For Policy and Econ, 12(3), 223-230.

Zhou, B., Gu, L., Ding, Y., Shao, L., Wu, Z., Yang, X., ...Kong, W. (2011). The great 2008 Chinese ice storm: its socioeconomic-ecological impact and sustainability lessons learned. Bull Am Meteorol Soc., 92, 47-60. http://dx.doi.org/10.1175/2010BAMS2857.1 


\section{Notes}

Note 1. Statistics on forests in China are difficult to obtain and interpret. Questions can be raised concerning plantation survival and the accuracy of area estimates. We leave these issues to one side for the present paper.

Note 2. Prefectures are administrative subdivisions of provincial level divisions and prefecture-level cities (pinyin: dijíshi) are municipalities that are given prefecture status and the right to govern surrounding counties. Sanming is a Prefecture-level city. Within the city's administrative boundaries is much rural and forested land, divided into counties (Appendix 3). The urban area of Sanming, the prefectural capital, is one district within the region.

Note 3. The mu is a traditional measure of land area in China. It is equal to $1 / 15$ of a hectare. It is a convenient unit for measuring individual landholdings.

Note 4. Hunting in various forms was long a preoccupation of the aristocracy. But in contrast, for example, to the US, individual ownership of firearms is forbidden in China.

\section{Appendixes}

Appendix 1. Evolution of forest tenure and market systems in non-state forests in Southern China

\begin{tabular}{|c|c|c|c|}
\hline Period & Institutional background & Ownership & Timber market \\
\hline Before 1950 & Semi-feudal, semi-capitalist & $\begin{array}{l}\text { Bureaucrats, landlords, timber } \\
\text { merchants and self-sustaining farmers }\end{array}$ & Free market \\
\hline $1950-1955$ & Land reform & $\begin{array}{l}\text { All farmers, including self-sustaining } \\
\text { farmers and former landlords }\end{array}$ & Free market \\
\hline $1956-1958$ & $\begin{array}{l}\text { Socialist transformation and } \\
\text { agricultural collectivization }\end{array}$ & Collective ownership & $\begin{array}{l}\text { Quotas and prices determined } \\
\text { by the state }\end{array}$ \\
\hline $1958-1979$ & People's communes & Collective ownership & $\begin{array}{l}\text { Quotas and prices determined } \\
\text { by the state }\end{array}$ \\
\hline $1979-1983$ & $\begin{array}{l}\text { Household-based agriculture(contract } \\
\text { responsibility) and people's communes }\end{array}$ & $\begin{array}{l}\text { Family forest plots; responsibility } \\
\text { forestland; collective forest }\end{array}$ & $\begin{array}{l}\text { Self-determined production; } \\
\text { compulsory delivery system }\end{array}$ \\
\hline 1984-1999 & Household-based agriculture & $\begin{array}{l}\text { Family forest plots; responsibility } \\
\text { forestland; collective forest; } \\
\text { shareholding system }\end{array}$ & $\begin{array}{l}\text { Price controls lifted, but taxes } \\
\text { and fees increased; government } \\
\text { monopoly on procurement }\end{array}$ \\
\hline 2000-now & $\begin{array}{l}\text { Household-based agriculture and new } \\
\text { round of forestland reform }\end{array}$ & $\begin{array}{l}\text { Family forest plots; responsibility } \\
\text { forestland; collective forest; } \\
\text { shareholding system; outsider } \\
\text { investors renting }\end{array}$ & $\begin{array}{l}\text { Logging ban in natural forest in } \\
17 \text { provinces; free market; } \\
\text { reduced taxes and importation } \\
\text { tariff }\end{array}$ \\
\hline
\end{tabular}

Source: summarization based on Sun (1992) and Liu (2006). 
Appendix 2. Major laws and some relevant regulations directing land tenure reform

Land tenure in general:

- $\quad$ Land Administration Law (1986; 1988; 1998; 2004)

- $\quad$ Rural Land Contract Law (2003)

- $\quad$ Property Rights Law (2007)

- $\quad$ The Law of the Mediation and Arbitration of Rural Land Contract Disputes (2010)

Natural resource management:

- $\quad$ Forestry Law $(1984 ; 1998)$

- $\quad$ Grassland Law $(1985 ; 2003)$

- $\quad$ Mineral Resources Law (1986; 1996)

- $\quad$ Water Resources Law (1988)

- $\quad$ Environmental Protection Law (1989)

- $\quad$ Law on the Wildlife Protection (1989)

- Water and Soil Conservation Law (1991)

- $\quad$ Agriculture Law (1993)

- $\quad$ Regulations on Wild Plants Protection (1997)

- $\quad$ Regulations for the implementation of the Forestry Law (2000)

- $\quad$ Law on the Prevention and Control of Desertification (2002)

- $\quad$ Coal Law(2006)

- $\quad$ Renewable Energy Law (2009)

- $\quad$ Law on Island Protection (2009)

Protected Areas:

- Construction Management Regulations of Scenic Areas (1993)

- $\quad$ Regulations on Natural Reserves (1994)

- $\quad$ Regulations on Forest Park Management (1994)

- $\quad$ Regulations on Scenic Areas (2006)

- $\quad$ [Draft] Natural Heritage Protection Act (2009)

Appendix 3. Current administrative jurisdictions in Mainland China

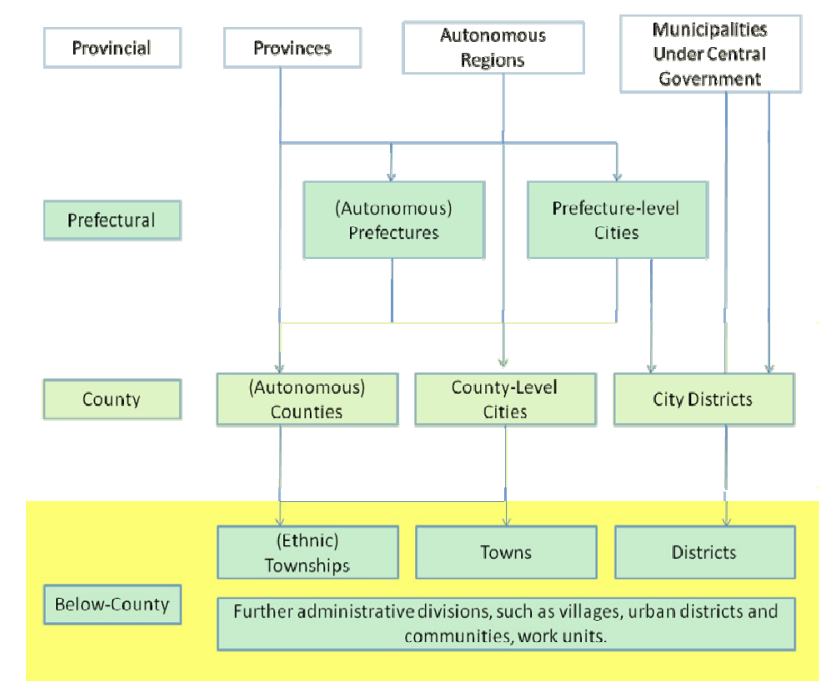

\section{Copyrights}

Copyright for this article is retained by the author(s), with first publication rights granted to the journal.

This is an open-access article distributed under the terms and conditions of the Creative Commons Attribution license (http://creativecommons.org/licenses/by/3.0/). 